\title{
MOTOR SKILLS DEVELOPMENT: OPTIMIZATION OF TEACHING BOYS AGED 14
}

\author{
Kapkan O.O. ${ }^{1}$, Khudolii O.M. ${ }^{2}$, Bartík P. ${ }^{3}$ \\ ${ }^{1}$ Donbas National Academy of Civil Engineering and Architecture \\ ${ }^{2}$ H.S. Skovoroda Kharkiv National Pedagogical University \\ ${ }^{3}$ Matej Bel University
}

Corresponding Author: Kapkan O.O., e-mail: ekapkan@gmail.com

Accepted for Publication: September 20, 2019

Published: September 25, 2019

DOI:10.17309/tmfv.2019.3.06

\begin{abstract}
The study objective is to substantiate the modes of alternation of physical exercises and rest intervals in the process of teaching series of tasks aimed at motor skills development in boys aged 14 years.

Materials and methods. The participants in the study were 40 boys aged 14 . The children and their parents were fully informed about all the features of the study and gave their consent to participate in the experiment. To achieve the objective set, the following research methods were used: study and analysis of scientific and methodological literature; pedagogical observation, timing of training tasks; pedagogical experiment, methods of mathematical statistics, methods of mathematical experiment planning.

Results. The results of the analysis of variance and regression models show that the optimal mode of performing series of training tasks is within the range of 6-12 exercise repetitions with rest intervals of 60-120 seconds. In the proposed matrix of factorial design, the selected step of factor variation is sufficient to study the impact of different modes of physical exercises on the effectiveness of teaching children and adolescents.

Conclusions. A $2^{2}$ type experiment made it possible to examine the multifactorial structure of the process of teaching boys aged 14, using the program of algorithmic instructions, to specify the optimal balance between factors for their use when teaching physical exercises during physical education classes.

The best options for teaching series of tasks to boys aged 14 during physical education classes are: series $1-12$ repetitions, rest interval of $120 \mathrm{~s}$; series $2-12$ repetitions, rest interval of $60 \mathrm{~s}$; series $3-6$ repetitions, rest interval of $60 \mathrm{~s}$; series $4-12$ repetitions, rest interval of $60 \mathrm{~s}$; series $5-12$ repetitions, rest interval of $120 \mathrm{~s}$; series $6-6$ repetitions, rest interval of $60 \mathrm{~s}$.

Keywords: boys, motor skills, training tasks, modes of exercises, factorial experiment.
\end{abstract}

\section{Introduction}

Current studies focus on discovering regularities of motor skills development in children and adolescents (Wright, 1999; Khudolii \& Ivashchenko, 2014; Ivashchenko, 2016) as a basis for professional excellence of physical education teachers (Rink, Jones, Kirby, Mitchell and Doutis, 2007).

The research papers by Chernenko (2015), Ivashchenko, Iermakov, Khudolii, Yermakova, Cieślicka and Harkusha (2018), Ivashchenko (2017) ascertained that the effectiveness of motor skills development is influenced by the modes of alternation of exercise repetitions and rest intervals. According to Samuel, Zavdy, Levav, Reuveny, Katz and Dubnov-Raz (2017), Balaban

(C) Kapkan O.O., Khudolii O.M., Bartík P., 2019.
(2018), physical activity can both stimulate and negatively affect cognitive activity and motor skills development in children. Regression analysis performed on the basis of a full $2^{\mathrm{k}}$ type factorial experiment data is an effective method for defining optimal modes of alternation of physical exercises and rest intervals during physical education classes (Ivashchenko, 2016).

In their papers, Khudolii \& Ivashchenko (2014), Lopatiev, Ivashchenko, Khudolii, Pjanylo, Chernenko and Yermakova (2017) substantiated the concept of pedagogical experiment in studying the process of building motor skills and developing learning models. The researchers ascertained the effectiveness of factorial designs for studying the regularities of teaching children and adolescents. The papers by Acher, Arca and Sanmarti (2007), Chatzipanteli, Digelidis, Karatzoglidis and Dean (2016) point to the importance of modeling in 
Table 1. Press headstand and handstand training program

\begin{tabular}{|c|c|c|}
\hline $\begin{array}{l}\text { Informative frame } \\
\text { (what is performed) }\end{array}$ & $\begin{array}{l}\text { Operational frame } \\
\text { (how it is performed) }\end{array}$ & $\begin{array}{c}\text { Control frame } \\
\text { (proceed to training the next } \\
\text { exercise) }\end{array}$ \\
\hline \multicolumn{3}{|c|}{ First series of training tasks - exercises for developing motor abilities } \\
\hline $\begin{array}{l}\text { From stoop standing position, with the back against } \\
\text { stall bars, proceed to arch hang }\end{array}$ & $\begin{array}{l}\text { Performed by jumping off both feet, hold } \\
\text { the position for } 3-4 \text { seconds }\end{array}$ & $\begin{array}{l}\text { If the student performs the exercise } \\
\text { correctly three times in a row, proceed } \\
\text { to the next exercise }\end{array}$ \\
\hline $\begin{array}{l}\text { In prone position, bend arms and knees ( } 5 \text { times in } \\
5-6 \text { seconds) }\end{array}$ & Performed with maximum amplitude & $\begin{array}{l}\text { If the student performs the exercise } \\
\text { for 5-6 seconds, proceed to the next } \\
\text { exercise }\end{array}$ \\
\hline \multicolumn{3}{|c|}{ Second series of training tasks - starting and ending positions } \\
\hline $\begin{array}{l}\text { From squatting position, lean forward, put the head } \\
\text { down on mat on the marking and evenly shift the } \\
\text { body weight to the head and arms }\end{array}$ & Hold the position for 3-4 seconds & $\begin{array}{l}\text { If the student performs the exercise } \\
\text { correctly three times in a row, proceed } \\
\text { to the next exercise }\end{array}$ \\
\hline \multicolumn{3}{|c|}{ Third series of training tasks - actions without which the exercise performance is impossible } \\
\hline $\begin{array}{l}\text { From squatting position, return to starting position } \\
\text { to perform a headstand and handstand. Straighten } \\
\text { the legs, transition to a headstand and handstand } \\
\text { with bent legs }\end{array}$ & $\begin{array}{l}\text { Transition to headstand and handstand } \\
\text { should be done by straightening the legs }\end{array}$ & $\begin{array}{l}\text { If the student performs the exercise } \\
\text { correctly three times in a row, proceed } \\
\text { to the next exercise }\end{array}$ \\
\hline \multicolumn{3}{|c|}{ Fourth series of training tasks - teaching to control movement time and muscular effort } \\
\hline $\begin{array}{l}\text { In kneeling position, bending and straightening of } \\
\text { the arms ( } 5 \text { times) }\end{array}$ & $\begin{array}{l}\text { Bend the arms simultaneously with } \\
\text { straightening the legs. Perform in } 5 \text { seconds }\end{array}$ & $\begin{array}{l}\text { If the student performs the exercise } \\
\text { for } 5-6 \text { seconds, proceed to the next } \\
\text { exercise }\end{array}$ \\
\hline $\begin{array}{l}\text { Bending and straightening of the arms in stoop } \\
\text { standing position ( } 5 \text { times) }\end{array}$ & $\begin{array}{l}\text { Plant the hands on the floor a step's length } \\
\text { away from the toes. Perform in } 5 \text { seconds }\end{array}$ & $\begin{array}{l}\text { If the student performs the exercise } \\
\text { for 5-6 seconds, proceed to the next } \\
\text { exercise }\end{array}$ \\
\hline $\begin{array}{l}\text { From normal standing position, lean forward, touch } \\
\text { the floor with the palms and, walking slowly on the } \\
\text { hands, adopt a prone position and return to starting } \\
\text { position in the same way }\end{array}$ & $\begin{array}{l}\text { Do not bend knees when performing the } \\
\text { exercise. Perform in } 6 \text { seconds }\end{array}$ & $\begin{array}{l}\text { If the student performs the exercise } \\
\text { for 5-6 seconds, proceed to the next } \\
\text { exercise }\end{array}$ \\
\hline \multicolumn{3}{|c|}{ Fifth series of training tasks - separate parts of the target exercise and preliminary exercises } \\
\hline $\begin{array}{l}\text { From squatting position, return to starting position } \\
\text { to perform a headstand and handstand. Straighten } \\
\text { the legs, transition to a headstand and handstand } \\
\text { with bent legs }\end{array}$ & $\begin{array}{l}\text { Straighten the back and hold balance with } \\
\text { bent legs for 3-4 seconds }\end{array}$ & $\begin{array}{l}\text { If the student performs the exercise } \\
\text { correctly three times in a row, proceed } \\
\text { to the next exercise }\end{array}$ \\
\hline $\begin{array}{l}\text { Perform a headstand and handstand, back and legs } \\
\text { against the wall, with assistance }\end{array}$ & Focus on the exercise technique & $\begin{array}{l}\text { If the student performs the exercise } \\
\text { correctly three times in a row, proceed } \\
\text { to the next exercise }\end{array}$ \\
\hline \multicolumn{3}{|c|}{ Sixth series of training tasks - performing the whole exercise } \\
\hline $\begin{array}{l}\text { Perform a headstand and handstand, back and legs } \\
\text { against the wall, without assistance }\end{array}$ & $\begin{array}{l}\text { Hold the headstand and handstand for 3-4 } \\
\text { seconds }\end{array}$ & $\begin{array}{l}\text { If the student performs the exercise } \\
\text { correctly three times in a row, proceed } \\
\text { to the next exercise }\end{array}$ \\
\hline Headstand and handstand without assistance & $\begin{array}{l}\text { Hold the headstand and handstand for 3-4 } \\
\text { seconds }\end{array}$ & $\begin{array}{l}\text { Correct performance of the series at } \\
\text { the third attempt }\end{array}$ \\
\hline
\end{tabular}

children's cognitive activity. According to García-Moya, Moreno and Jiménez-Iglesias (2012), Wang, Karns, and Meredith (2003), the use of factorial designs in studies involving adolescents and children helps to obtain objective information about the dynamics of physical development. The validity of using a full $2^{\mathrm{k}}$ type factorial experiment is confirmed by the data of Correa, Grima, and Tort-Martorell $(2009,2012)$, Kapkan, Khudolii and Bartik (2018, 2019).

An important element in building motor skills is pedagogical control of motor abilities development and the dynamics of proficiency level in physical exercises
(Khudolii, \& Iermakov, 2011; Ivashchenko, 2016). Discriminant analysis is an effective method for assessing schoolchildren's state. It allows to classify schoolchildren by the level of motor skills development (Cantell, Smyth, \& Ahonen, 2003; Donovan, Mercier, \& Phillips, 2015), as well as to determine the informative value of a test battery for assessing the impact of physical training on the basic motor competences (Herrmann, Gerlach, \& Seelig, 2016; Ivashchenko, 2016; Kapkan, Khudolii, \& Bartik, 2018).

Thus, physical exercises modes in the process of acquisition of series of training tasks within programmed 
learning remain underexplored. The problem of control over schoolchildren's learning process needs further research.

The study objective is to substantiate the modes of alternation of physical exercises and rest intervals in the process of teaching series of tasks aimed at motor skills development in boys aged 14 years.

\section{Materials and methods}

\section{Study participants}

The participants in the study were 40 boys aged 14. The children and their parents were fully informed about all the features of the study and gave their consent to participate in the experiment.

\section{Study organization}

To achieve the objective set, the following research methods were used: study and analysis of scientific and methodological literature; pedagogical observation, timing of training tasks; pedagogical experiment, methods of mathematical statistics, methods of mathematical experiment planning.

During the learning process, the study used a method of algorithmic instructions. The press headstand and handstand training program included training tasks given in Table 1 . The student could proceed to the next exercise only after a correct performance of the previous exercise on three consecutive attempts. The number of repetitions needed to teach exercises in each series of training tasks was recorded. The level of proficiency in the physical exercises performance was determined by the alternative method: "performed" or "failed". A technically correct performance of the exercise gave the students " 1 " point; a failure to perform the exercise gave them " 0 " entered in the protocol.

To achieve the objective set, the study examined the effect of different variants of exercises, specifically: the number of repetitions $\left(x_{1}\right)$ and rest intervals $\left(x_{2}\right)$ on mastering a press headstand technique. The boys aged 14 were divided into four groups according to the experiment plan. The differences between the groups in the lesson plan resulted from the factorial experiment conditions presented in Table 2. The bottom and top levels of the factors were chosen based on the data provided by Khudolii and Ivashchenko (2014), Ivashchenko (2016), Chernenko (2015), and were limited to the lesson framework.

\section{Statistical analysis}

The paper used the methods of analyzing the results of mathematical experiment planning of a full $2^{\mathrm{K}}$ type
Table 2. $2^{2}$ type factorial design

\begin{tabular}{ccc}
\hline Variants of & \multicolumn{2}{c}{ Modes of training } \\
\cline { 2 - 3 } exercises & Repetition number & Rest interval \\
\hline 1 & $6-$ & $60-$ \\
2 & $12+$ & $60-$ \\
3 & $6-$ & $120+$ \\
4 & $12+$ & $120+$ \\
\hline
\end{tabular}

factorial experiment (Khudolii \& Ivashchenko, 2014; Ivashchenko, 2016). The study materials were processed by the IBM SPSS 20 statistical analysis software.

The study protocol was approved by the Ethical Committee of the University. In addition, the children and their parents or legal guardians were fully informed about all the features of the study, and a signed informed-consent document was obtained from all the parents.

\section{Study results}

Table 3 shows the results of analysis of a full $2^{2}$ type factorial experiment.

The analysis of regression equations allowed us to conclude that:

- in the first series of training tasks, the most influential factor is the duration of rest interval $\left(x_{2}\right)$, the second most influential factor is the relationship between the number of repetitions and rest intervals $\left(x_{1} x_{2}\right)$, the third - the number of repetitions $(x 1)$. To improve the effectiveness of training, it is necessary to increase the number of repetitions from 6 to 12 times and increase rest intervals $\left(x_{2}\right)$ from 60 to 120 seconds.

- in the second series of training tasks, the most influential factor is the number of repetitions $\left(x_{1}\right)$, the duration of rest interval $\left(x_{2}\right)$ and the relationship between the number of repetitions and rest interval $\left(x_{1} x_{2}\right)$ are far less influential. To improve the effectiveness of training, it is necessary to increase the number of repetitions from 6 to 12 times and reduce the rest interval from 120 to 60 seconds.

- in the third series of training tasks, the most influential factor is the duration of rest interval $\left(x_{2}\right)$, the second most influential factor is the relationship between the number of repetitions and rest interval $\left(x_{1} x_{2}\right)$, the third - the number of repetitions $\left(x_{1}\right)$. To improve the effectiveness of training, it is necessary to reduce the number of repetitions from 12 to 6 times and reduce the rest interval from 120 to 60 seconds.

- in the fourth series of training tasks, the most influential factor is the duration of rest interval $\left(x_{2}\right)$, the second most influential factor is the 
Table 3. Results of analysis of a full $2^{2}$ type factorial experiment. Boys aged 14

\begin{tabular}{|c|c|c|c|c|}
\hline \multirow[t]{2}{*}{$\begin{array}{l}\text { Series of train- } \\
\text { ing tasks }\end{array}$} & \multirow[t]{2}{*}{ Regression equations } & \multicolumn{3}{|c|}{$\begin{array}{c}\text { Percentage contribution to achievement } \\
\text { of target indicator }\end{array}$} \\
\hline & & $x_{1}$ & $x_{2}$ & $x_{1} x_{2}$ \\
\hline 1 & $\mathrm{Y}=6.925+1.475 x_{1}+1.875 x_{2}+1.725 x_{1} x_{2}$ & 25 & 40 & 34 \\
\hline 2 & $\mathrm{Y}=9.075+2.225 x_{1}$ & 93 & 3 & 2 \\
\hline 3 & $\mathrm{Y}=13.9-1.15 x_{2}-1.05 x_{1} x_{2}$ & 12 & 47 & 39 \\
\hline 4 & $\mathrm{Y}=13.6+0.85 x_{1}+2.2 x_{2}-1.15 x_{1} x_{2}$ & 10 & 70 & 19 \\
\hline 5 & $\mathrm{Y}=9.35+1.55 x_{2}+1.4 x_{1} x_{2}$ & 2 & 53 & 44 \\
\hline 6 & $\mathrm{Y}=8.425-1.075 x_{1}-2.775 x_{1} x_{2}$ & 13 & 0 & 86 \\
\hline
\end{tabular}

relationship between the number of repetitions and rest interval $\left(x_{1} x_{2}\right)$, the third - the number of repetitions $\left(x_{1}\right)$. To improve the effectiveness of training, it is necessary to increase the number of repetitions from 6 to 12 times and reduce the rest interval from 120 to 60 seconds.

- in the fifth series of training tasks, the most influential factor is the duration of rest interval $\left(x_{2}\right)$, the relationship between the number of repetitions and rest interval $\left(x_{1} x_{2}\right)$ and the number of repetitions $\left(x_{1}\right)$ are less influential. To improve the effectiveness of training, it is necessary to increase the number of repetitions from 6 to 12 times and the rest interval $\left(x_{2}\right)$ from 60 to 120 seconds.

- in the sixth series of training tasks, the most influential factor is the relationship between the number of repetitions and rest interval $\left(x_{1} x_{2}\right)$, the second most influential factor is the number of repetitions $\left(x_{1}\right)$. To improve the effectiveness of training, it is necessary to reduce the number of repetitions from 12 to 6 times and reduce the rest interval from 120 to 60 seconds.

The analysis of variance shows:

- in the first series of training tasks, the learning process is most influenced by the second factor $\left(x_{2}\right)$, the percentage contribution is $40 \%$, as well as by the relationship between both factors $\left(x_{1} x_{2}\right)$, the percentage contribution is $34 \%$, and the first factor $\left(x_{1}\right)$, the percentage contribution is $25 \%$;

- in the second series of training tasks, the learning process is most influenced by the first factor $\left(x_{1}\right)$, the percentage contribution is $93 \%$, the second factor $\left(x_{2}\right)$, the percentage contribution is $3 \%$, and the relationship between both factors $\left(x_{1} x_{2}\right)$, the percentage contribution is $2 \%$;

- in the third series of training tasks, the learning process is most influenced by the second factor $\left(x_{2}\right)$, the percentage contribution is $47 \%$, as well as by the relationship between both factors $\left(x_{1} x_{2}\right)$, the percentage contribution is $39 \%$, and the first factor $\left(x_{1}\right)$, the percentage contribution is $12 \%$;

- in the fourth series of training tasks, the learning process is most influenced by the second factor $\left(x_{2}\right)$, the percentage contribution is $70 \%$, as well as by the relationship between both factors $\left(x_{1} x_{2}\right)$, the percentage contribution is $19 \%$, and the first factor $\left(x_{1}\right)$, the percentage contribution is $10 \%$;

- in the fifth series of training tasks, the learning process is most influenced by the second factor $\left(x_{2}\right)$, the percentage contribution is $53 \%$, as well as by the relationship between both factors $\left(x_{1} x_{2}\right)$, the percentage contribution is $44 \%$, the first factor $\left(x_{1}\right)$, the percentage contribution is $20 \%$;

- in the sixth series of training tasks, the learning process is most influenced by the relationship between both factors $\left(x_{1} x_{2}\right)$, the percentage contribution is $86 \%$, the first factor $\left(x_{1}\right)$, the percentage contribution is $13 \%$.

Consequently, the best options for teaching series of tasks to boys aged 14 are:

series $1-12$ repetitions, rest interval of $120 \mathrm{~s}$; series $2-12$ repetitions, rest interval of $60 \mathrm{~s}$; series $3-6$ repetitions, rest interval of $60 \mathrm{~s}$; series $4-12$ repetitions, rest interval of $60 \mathrm{~s}$; series $5-12$ repetitions, rest interval of $120 \mathrm{~s}$; series $6-6$ repetitions, rest interval of $60 \mathrm{~s}$.

\section{Discussion}

The study assumed that the effectiveness of acquisition of series of training tasks depends on the mode of alternation of exercises and rest intervals. The results of the analysis of variance and regression models show that the optimal mode of performing series of training tasks is within the range of 6-12 exercise repetitions with rest intervals of 60-120 seconds. In the proposed matrix of factorial design, the selected step of factor 
variation is sufficient to study the impact of different modes of physical exercises on the effectiveness of teaching children and adolescents (Table 2).

The findings enhance and supplement the data obtained by Khudolii, and Ivashchenko (2014), Ivashchenko (2016) on the effectiveness of using factorial designs when studying children's and adolescents' learning process and motor abilities development; Kapkan's (2015) data on the possibility of improving the effectiveness of the learning process based on the analysis of regression models and calculation of modes of alternation of physical exercises and rest intervals in the process of motor skills development in schoolchildren aged 14-15 during physical education classes. The findings confirm Ivashchenko's (2016) data showing that a full factorial experiment method makes it possible to mathematically describe the process in some local area of the factorial space around the point with the coordinates of the ndimensional space and to verify the regression model; allows to evaluate the effectiveness and reliability of a $2^{2}$ type factorial design in determining the effects of different modes of training on the change in children's functional state and ability to learn movements.

According to García-Moya, Moreno, and JiménezIglesias (2012), Wang, Karns, and Meredith (2003), the use of factorial designs in studies involving adolescents and children increases the objectivity of evaluation of their development indicators. The effectiveness of using a full $2^{\mathrm{k}}$ type factorial experiment, the objectivity of data obtained through factorial designs are confirmed by the data of Correa et al. (2009, 2012), Ivashchenko, Khudolii, Iermakov, Chernenko, and Honcharenko (2018).

The data obtained supplement the studies by Chernenko (2015), Ivashchenko, Abdulkhalikova, and Cieślicka (2017), Ivashchenko, Khudolii, Iermakov, and Harkusha (2017) that found that the control over the learning process is more effective if the modes of teaching are defined based on regression models.

\section{Conclusions}

A $2^{2}$ type experiment made it possible to study the multifactorial structure of the process of teaching boys aged 14, using the program of algorithmic instructions, to specify the optimal balance between factors for their use when teaching physical exercises during physical education classes.

The best options for teaching series of tasks to boys aged 14 during physical education classes are:

series $1-12$ repetitions, rest interval of $120 \mathrm{~s}$; series $2-12$ repetitions, rest interval of $60 \mathrm{~s}$; series $3-6$ repetitions, rest interval of $60 \mathrm{~s}$; series $4-12$ repetitions, rest interval of $60 \mathrm{~s}$; series $5-12$ repetitions, rest interval of $120 \mathrm{~s}$; series $6-6$ repetitions, rest interval of $60 \mathrm{~s}$.

The prospect for further exploration is to study the regularities of teaching physical exercises to boys aged 15 .

\section{Acknowledgment}

The research was carried out according to the theme 13.04 "Modelling of the learning process and development of motor abilities in children and adolescents" (2013-2014) (state registration number 0113U002102).

\section{Conflict of Interest}

The authors state that there is no conflict of interest.

\section{References}

Wright Steven (1999). A compatative view of teaching practice in Physical Education. International Sports Studies, 21(1), 55-68.

Khudolii, O.M., \& Ivashchenko, O.V. (2014). Simulation of the learning process and development of motor abilities in children and adolescents: Monograph. Kharkiv : OVS, 320. (in Ukrainian)

Ivashchenko, O.V. (2016). Modelling of physical education students: Monograph. Kharkiv: OVS (in Ukrainian)

Judith Rink, Laura Jones, Kym Kirby, Murray Mitchell, \& Panayiotis Doutis (2007). Teacher Perceptions of a Physical Education Statewide Assessment Program. Research Quarterly for Exercise and Sport, 78(3), 204 215. https://doi.org/10.1080/02701367.2007.10599418

Chernenko, S.O. (2015). Effectieness of junior form pupils' training of gymnastic exercises in different modes of their fulfillment. Pedagogics, Psychology, Medical-Biological Problems Of Physical Training And Sports, 19(8), 65-74. https://doi. org/10.15561/18189172.2015.0809

Ivashchenko, O., Iermakov, S., Khudolii, O., Yermakova, T., Cieślicka, M., \& Harkusha, S. (2018). Simulation of the regularities of physical exercises learning process of boys aged 8 years old. Pedagogics, Psychology, Medical-Biological Problems of Physical Training and Sports, 22(1), 11-16. https://doi. org/10.15561/18189172.2018.0102

Ivashchenko, O. (2017). Classification of 11-13 yrs girls' motor fitness, considering level of physical exercises' mastering. Pedagogics, Psychology, Medical-Biological Problems of Physical Training and Sports, 21(2), 65-70. https://doi.org/10.15561/18189172.2017.0203

Samuel, R. D., Zavdy, O., Levav, M., Reuveny, R., Katz, U., \& Dubnov-Raz, G. (2017). The Effects of Maximal Intensity Exercise on Cognitive Performance in Children. Journal of Human Kinetics, 57(1), 85-96. https://doi.org/10.1515/hukin-2017-0050

Balaban, V. (2018). The relationship between objectively measured physical activity and fundamental motor skills in 8 to 11 years old children from the Czech Republic. Montenegrin Journal of Sports Science 
and Medicine, 7(2), 11-16. https://doi.org/10.26773/ mjssm. 180902

Lopatiev, A., Ivashchenko, O., Khudolii, O., Pjanylo, Y., Chernenko, S. \& Yermakova T. (2017). Systemic approach and mathematical modeling in physical education and sports. Journal of Physical Education and Sport (JPES), 17(1), suplement, 146-155. https:// doi.org/10.7752/jpes.2017.s1023

Acher, A., Arca, M., \& Sanmarti, N. (2007). Modeling as a teaching learning process for understanding materials: A case study in primary education. Science Education, 91(3), 398-418. https://doi.org/10.1002/sce.20196

Chatzipanteli, A., Digelidis, N., Karatzoglidis, C., \& Dean, R. (2016). A tactical-game approach and enhancement of metacognitive behaviour in elementary school students. Physical Education and Sport Pedagogy, 21(2),169-184. https://doi.org/10.1080/17408989.2014 .931366

García-Moya, I., Moreno, C., \& Jiménez-Iglesias, A. (2012). Building a composite factorial score for the assessment of quality of parent-child relationships in adolescence. European Journal of Developmental Psychology, 10(5), 642-648. https://doi.org/10.1080/17405629.2012.7077 81

Wang, A., Karns, J. T., \& Meredith, W. (2003). Motivation, Stress, Self-Control Ability, and Self-Control Behavior of Preschool Children in China. Journal of Research in Childhood Education, 17(2), 175-187. https://doi. org/10.1080/02568540309595008

Correa, A. A., Grima, P., \& Tort-Martorell, X. (2009). Experimentation order with good properties for $2 \mathrm{k}$ factorial designs. Journal of Applied Statistics, 36(7), 743-754. https://doi.org/10.1080/02664760802499337

Correa, A. A., Grima, P., \& Tort-Martorell, X. (2012). Experimentation order in factorial designs: new findings. Journal of Applied Statistics, 39(7), 15771591. https://doi.org/10.1080/02664763.2012.661706

Kapkan, O., Khudolii, O., \& Bartik, P. (2018). Pattern Recognition: Physical Exercises Modes During Motor Skills Development in Girls Aged 14. Teorîa Ta Metodika Fìzičnogo Vihovannâ, 18(4), 167-174. https:// doi.org/10.17309/tmfv.2018.4.02

Kapkan, O., Khudolii, O., \& Bartik, P. (2019). Pattern Recognition: Motor Skills Development in Girls Aged
15. Teoriâ Ta Metodika Fìzičnogo Vihovannâ, 19(1), 44-52. https://doi.org/10.17309/tmfv.2019.1.06

Khudolii, O. M., \& Iermakov, S. S. (2011). Regularities of the learning process of young gymnasts. Teoriâ ta Metodika Fìzičnogo Vihovannâ, 0(5), 3-18, 35-41. (in Ukrainian) https://doi.org/10.17309/tmfv.2011.5.707

Cantell, M. H., Smyth, M. M., \& Ahonen, T. P. (2003). Two distinct pathways for developmental coordination disorder: Persistence and resolution. Human Movement Science, 22(4-5), 413-431. https://doi. org/10.1016/j.humov.2003.09.002

Donovan, C. B., Mercier, K., \& Phillips, S. R. (2015). Investigating Attitudes Toward Physical Education: Validation Across Two Instruments. Measurement in Physical Education and Exercise Science, 19(2), 91-98. https://doi.org/10.1080/1091367X.2015.1012511

Herrmann, C., Gerlach, E., \& Seelig, H. (2016). Basic motor competences in primary school. Rationale, assessment and empirical testing of a measurement instrument. German Journal of Exercise and Sport Research, 46(2), 60-73. https://doi.org/10.1007/s12662-015-0378-8

Kapkan, O.O. (2015). Features of 14-15 years' age boys' training to physical exercises. Pedagogics, Psychology, Medical-Biological Problems Of Physical Training And Sports, 19(9), 26-32. https://doi. org/10.15561/18189172.2015.0904

Ivashchenko, O., Khudolii, O., Iermakov, S., Chernenko, S., \& Honcharenko, O. (2018). Full factorial experiment and discriminant analysis in determining peculiarities of motor skills development in boys aged 9. Journal of Physical Education and Sport, 18, 1958-1965. https:// doi.org/10.7752/jpes.2018.s4289

Ivashchenko, O., Abdulkhalikova, T., \& Cieślicka, M. (2017). Effectiveness of Motor Skills Development in 5th-7th Grade Boys at Different Modes of Physical Exercises. Teorìa Ta Metodika Fìzičnogo Vihovannâ, 17(4), 201207. https://doi.org/10.17309/tmfv.2017.4.1205

Ivashchenko, O., Khudolii, O., Iermakov, S., \& Harkusha, S. (2017). Physical exercises' mastering level in classification of motor preparedness of 11-13 years old boys. Journal of Physical Education and Sport ${ }^{\circledR}$ (JPES), 17(3), 1031-1036. https://doi.org/10.7752/ jpes. 2017.03158 


\title{
ФОРМУВАННЯ РУХОВИХ НАВИЧОК: ОПТИМІЗАЦІЯ РЕЖИМУ НАВЧАННЯ ХЛОПЦІВ 14 РОКІВ
}

\author{
Капкан O.O. ${ }^{1}$, Худолій О.М. ${ }^{2}$, Бартік $\Pi .^{3}$ \\ ${ }^{1}$ Донбаська національна академія будівництва і архітектури \\ ${ }^{2}$ Харківський національний педагогічний університет імені Г.С. Сковороди \\ ${ }^{3}$ Університет Матея Беля \\ Реферат. Стаття: 7 с., 3 табл., 26 джерело.
}

\begin{abstract}
Мета дослідження - обгрунтувати режими чергування виконання фізичних вправ та інтервалів відпочинку у процесі навчання серій завдань спрямованих на формування рухових навичок у хлопців 14 років.

Матеріали і методи. Учасниками дослідження були 40 хлопчиків у віці 14 років. Діти та їхні батьки були повністю поінформовані про всі особливості дослідження та погодилися взяти участь в експерименті. Для досягнення поставленої мети були використані такі методи дослідження: вивчення та аналіз наукової та методичної літератури; педагогічне спостереження, хронометраж виконання навчальних завдань; педагогічний експеримент, методи математичної статистики, методи математичного планування експерименту.

Результати. Результати дисперсійного аналізу та регресійних моделей свідчать, що в діапазоні 6-12 повторень вправи з інтервалами відпочинку 60-120 с знаходиться оптимальний режим виконання серій навчальних завдань. У запропонованій матриці плану факторного експерименту вибраний крок ва-
\end{abstract}

ріювання факторів є достатнім для вивчення впливу різних режимів виконання фізичних вправ на ефективність навчання дітей і підлітків.

Висновки. Експеримент типу $2^{2}$ надав змогу дослідити багатофакторну структуру процесу навчання хлопців 14 років за програмою алгоритмічних розпоряджень, уточнити оптимальні співвідношення факторів для їх використання у період навчання фізичних вправ під час уроків фізичної культури.

Оптимальними варіантами умов навчання серіям завдань хлопців 14 років на уроках фізичної культури є: 1 серія - 12 повторень, інтервал відпочинку 120 c; 2 серія - 12 повторень, інтервал відпочинку 60 с; 3 серія -6 повторень, інтервал відпочинку 60 c; 4 серія - 12 повторень, інтервал відпочинку 60 c; 5 серія - 12 повторень, інтервал відпочинку 120 c; 6 серія - 6 повторень, інтервал відпочинку 60 c.

Ключові слова: хлопці, рухові навички, навчальні завдання, режими виконання вправ, факторний експеримент.

\section{ФОРМИРОВАНИЕ ДВИГАТЕЛЬНЫХ НАВЫКОВ: ОПТИМИЗАЦИЯ РЕЖИМА ОБУЧЕНИЯ РЕБЯТ 14 ЛЕТ}

\author{
Капкан Е.А. ${ }^{1}$, Худолей О.Н. ${ }^{2}$, Бартик П. ${ }^{3}$ \\ ${ }^{1}$ Донбасская государственная машиностроительная академия \\ ${ }^{2}$ Харьковский национальный педагогический университет имени Г. С. Сковороды \\ ${ }^{3}$ Университет Матея Беля \\ Реферат. Статья: 7 с., 3 табл., 26 источник.
}

Цель исследования - обосновать режимы чередования выполнения физических упражнений и интервалов отдыха в процессе обучения серий заданий направленных на формирование двигательных навыков у ребят 14 лет.

Материалы и методы. Участниками исследования были 40 мальчиков в возрасте 14 лет. Дети и их родители были полностью информированы обо всех особенностях исследования и согласились принять участие в эксперименте. Для достижения поставленной цели были использованы следующие методы исследования: изучение и анализ научной и методической литературы; педагогическое наблюдение, хронометрирование выполнения учебных заданий; педагогический эксперимент, методы математической статистики, методы математического планирования эксперимента.

Результаты. Результаты дисперсионного анализа и регрессионных моделей свидетельствуют, что в диапазоне 6-12 повторений упражнения с интерва- 
лами отдыха 60-120 с находится оптимальный режим выполнения серий учебных заданий. В предлагаемой матрице плана факторного эксперимента выбраный шаг варьирования факторов является достаточным для изучения влияния различных режимов выполнения физических упражнений на эффективность обучения детей и подростков.

Выводы. Эксперимент типа $2^{2}$ предоставил возможность исследовать многофакторную структуру процесса обучения ребят 14 лет по программе алгоритмических предписаний, уточнить оптимальные соотношения факторов для их использования в период обучения физических упражнений на уроках физической культуры.
Оптимальными вариантами условий обучения сериям заданий ребят14 лет на уроках физической культуры являются: 1 серия - 12 повторений, интервал отдыха 120 c; 2 серия - 12 повторений, интервал отдыха 60 c; 3 серия - 6 повторений, интервал отдыха 60 c; 4 серия - 12 повторений, интервал отдыха 60 с; 5 серия - 12 повторений, интервал отдыха 120 с; 6 серия - 6 повторений, интервал отдыха 60 с.

Ключевые слова: ребята, двигательные навыки, учебные задания, режимы выполнения упражнений, факторный эксперимент.

\section{Information about the authors:}

Kapkan O.O.: ekapkan@gmail.com; http://org/0000-0003-4320-4276; Department of Physical Education Donbas National Academy of Civil Engineering and Architecture; Nebesnoi Sotni St, 14, Kramatorsk, 84333, Ukraine.

Khudolii O.M.: khudolii.oleg@gmail.com; http://orcid.org/0000-0002-5605-9939; Department of Theory and Methodology of Physical Education, Health and Medical Physical Culture, H. S. Skovoroda Kharkiv National Pedagogical University, Alchevskikh St, 29, Kharkiv, 61002, Ukraine.

Bartík P.: pavol.bartik@umb.sk; https://orcid.org/0000-0002-2087-7876; Department of Physical Education and Sports, Matej Bel University. Tajovského 40, 97401 Banská Bystrica, Slovakia.

Cite this article as: Kapkan, O.O., Khudolii, O.M., \& Bartík, P. (2019). Motor Skills Development: Optimization of Teaching Boys Aged 14. Teoriâ ta Metodika Fizičnogo Vihovannâ, 19(3), 148-155.

https://doi.org/10.17309/tmfv.2019.3.06

Received: 14.08.2019. Accepted: 20.09.2019. Published: 25.09.2019

This work is licensed under a Creative Commons Attribution 4.0 International License (http://creativecommons.org/ licenses/by/4.0). 